GLOBAL WATER PATHOGEN PROJECT

PART FOUR. MANAGEMENT OF RISK FROM EXCRETA AND WASTEWATER

\title{
ACTIVATED SLUDGE
}

\section{Colleen Naughton}

University of South Florida

Tampa, United States

Olivier Rousselot

Service public de l'assainissement francilien

Paris, France 


\section{Copyright:}

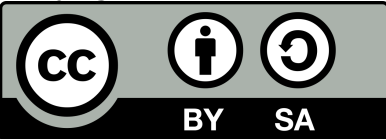

This publication is available in Open Access under the Attribution-ShareAlike 3.0 IGO (CC-BY-SA 3.0 IGO) license (http://creativecommons.org/licenses/by-sa/3.0/igo). By using the content of this publication, the users accept to be bound by the terms of use of the UNESCO Open Access Repository (http://www.unesco.org/openaccess/terms-use-ccbysa-en).

\section{Disclaimer:}

The designations employed and the presentation of material throughout this publication do not imply the expression of any opinion whatsoever on the part of UNESCO concerning the legal status of any country, territory, city or area or of its authorities, or concerning the delimitation of its frontiers or boundaries. The ideas and opinions expressed in this publication are those of the authors; they are not necessarily those of UNESCO and do not commit the Organization.

\section{Citation:}

Naughton, C. and Rousselot, O. (2017). Activated Sludge. In: J.B. Rose and B. Jiménez-Cisneros (eds), Water and Sanitation for the 21st Century: Health and Microbiological Aspects of Excreta and Wastewater Management (Global Water Pathogen Project). (J.R. Mihelcic and M.E. Verbyla (eds), Part 4: Management Of Risk from Excreta and Wastewater - Section: Sanitation System Technologies, Pathogen Reduction in Sewered System Technologies), Michigan State University, E. Lansing, MI, UNESCO. https://doi.org/10.14321/waterpathogens.62

Acknowledgements: K.R.L. Young, Project Design editor; Website Design: Agroknow (http://www.agroknow.com)

Last published: August 17, 2017 


\section{Summary}

Activated sludge is a sanitation technology that use biological processes and can be deployed in a semicentralized or centralized manner. An activated sludge system consists of one or more reactors, in which microorganisms responsible for treatment are kept in suspension and a solid-liquid separation is performed in a secondary clarifier that follows the activated sludge process or by membrane filtration. Sludge and/or water is recirculated between the biological reactor and the secondary clarifier. Activated sludge systems are frequently used in combination with other sanitation technologies. They require mechanical aeration which is costly and increases their carbon footprint relative to other technologies. However, they are efficient at removing conventional pollutants and require a smaller physical footprint than some other sanitation technologies. Activated sludge systems are typically located after preliminary and primary treatment of the wastewater and before advanced tertiary treatment. The average removal of pathogens in the liquid phase that can be expected to occur in an activated system is $1.5 \log _{10}$ for bacteria, $1.8 \log _{10}$ for viruses and viral indicators, $1.3 \log _{10}$ removal for protozoa, and $0.65 \log _{10}$ removal for helminths. There is a lot of variation of pathogen removal efficiencies between different activated sludge reactor configurations and also between the same reactor configuration depending on the plant's influent characteristics, environmental and operational parameters. Pathogens are transferred from the liquid phase to the solids (sludge) in activated sludge, however, some removal does occur during the solids separation process through pathogen degradation and predation. It can be expected that the following removal of pathogens will occur in the generated sludge during the solids separation process: $0.63 \log _{10}$ removal of virus-like particles, $0.70 \log _{10}$ removal of viral indicators, and $1.5 \log _{10}$ removal of bacterial indicators (fecal coliforms and fecal streptococci). Bioaerosol concentrations from activated sludge systems are dependent on a number of operational and environmental parameters. When inhaled from the air or ingested after touching a contaminated surface, they may cause negative health consequences to plant workers.
Neighboring communities could also be at risk if concentrations are high enough and they are in close proximity. This chapter thus provides microbial numbers and composition that have been detected in bioaerosols associated with the activated sludge process.

\subsection{Brief Technology Description}

Activated sludge systems are a widely used biological wastewater treatment system that can be deployed in a semi-centralized or centralized manner (Carducci and Verani, 2013). The highlighted wastewater treatment sector in Figure 1 shows where activated sludge systems can be used within the sanitation service chain. Their design has evolved considerably since their introduction at the start of the twentieth century due to several factors: 1) the necessity to obtain a better quality of treated water, 2) an improved understanding of microbial processes, 3) technologically improved equipment (e.g. air turbo charger and diffusers, centrifugal or eccentric helical rotor pumps), 4) better instrumentation (e.g. measurements of flow, dissolved oxygen, organic carbon, and ammonia), 5) progress in automation, and 6) optimization of capital and operating expenditures (CAPEX and OPEX). Regardless of these improvements, because of their aeration requirements, activated sludge plants still require a large input of energy (Muga and Mihelcic, 2008).

There are many different variations of activated sludge reactors and multistep systems including: conventional (see Figure 2), extended aeration, oxidation ditch, deep shaft, sequencing batch reactors (SBRs), Integrated Fixed Film Activated Sludge (IFAS), and anaerobic, anoxic, and oxic activated sludge system (A20) (see bottom left of Figure 2). Different types of activated sludge systems may include and be adjusted for greater nitrogen (and nitrates) and biological phosphorus removal (e.g. oxidation ditch, sequencing batch reactors (SBRs), A2O, etc.). Some examples of process modifications to the activated sludge process are shown in Table 1. Process modifications are related to whether the reactor is designed as a plug flow or completely mixed flow reactor and the way that the wastewater and oxygen are introduced to the system (Mihelcic and Zimmerman, 2014). 
Table 1. Examples of Process Modifications Made to the Conventional Activated-Sludge System

\begin{tabular}{|c|c|}
\hline & Description \\
\hline $\begin{array}{l}\text { Conventional } \\
\text { activated sludge }\end{array}$ & $\begin{array}{l}\text { Primary effluent and return activated sludge (RAS) are introduced at the head of the aeration } \\
\text { basin. Aeration is provided in a non-uniform manner over the length of the tank as more aeration } \\
\text { is required at the beginning of the tank, since the organic loading is higher there because the BOD } \\
\text { is removed along the length of the aeration basin. }\end{array}$ \\
\hline Step feed aeration & $\begin{array}{l}\text { A modification where primary clarifier effluent is introduced at several points along the beginning } \\
\text { of the aeration basin. The peak oxygen demand is thus more evenly distributed throughout the } \\
\text { aeration tank. Aeration is uniform along the length of the aeration basin. }\end{array}$ \\
\hline Contact stabilization & $\begin{array}{c}\text { The aeration basin is separated into a stabilization zone followed by a small contact zone. Primary } \\
\text { clarifier effluent is routed to the contact zone first. Return activated sludge is recycled back into } \\
\text { the stabilization zone. }\end{array}$ \\
\hline Extended & $\begin{array}{l}\text { Similar to conventional activated sludge except the primary clarifier is usually eliminated, SRT is } \\
\text { very long (20-30 days), and hydraulic retention times are close to } 1 \text { day. Used primarily by smaller } \\
\text { communities, schools, and resorts. }\end{array}$ \\
\hline Oxidation ditch & $\begin{array}{l}\text { Oval reactors where wastewater moves at relati } \\
\text { recycled back to the bec }\end{array}$ \\
\hline $\begin{array}{l}\text { Sequencing batch } \\
\text { reactor }\end{array}$ & $\begin{array}{l}\text { Fill and draw reactors where a minimum of two reactors are used. While one reactor is being } \\
\text { filled, biological reactions, settling of solids, and removal of settled wastewater are occurring in } \\
\text { the other reactor. }\end{array}$ \\
\hline $\begin{array}{l}\text { Moving Bed Bio(film) } \\
\text { Reactor and } \\
\text { Integrated Fixed Film } \\
\text { Activated Sludge } \\
\text { (IFAS) }\end{array}$ & $\begin{array}{l}\text { An MBBR system, like conventional activated sludge, includes an aeration tank but the tank is } \\
\text { filled with special plastic media/carriers. The plastic carriers have high surface area for biofilm to } \\
\text { grow which degrade organic matter in the wastewater. MBBR doesn't necessarily included } \\
\text { recirculation of sludge (Return Activated Sludge), however IFAS does and is increasingly used to } \\
\text { retrofit existing conventional activated sludge treatment plants to treat greater loads of } \\
\text { wastewater with limited space for expansion. }\end{array}$ \\
\hline
\end{tabular}

Adapted from Mihelcic and Zimmerman, 2014 with permission of John Wiley \& Sons, Inc. Copyright@ 2014 , 2010 John Wiley \& Sons, Inc. All rights reserved.

The general principle of all activated sludge systems are based on three elements:

1. They contain one or more reactors, in which microorganisms responsible for treatment are kept in suspension (free or sometimes fixed to floating support such as in Integrated Fixed Film Activated Sludge (IFAS)), and are operated with or without oxygenation/aeration and mixing,

2. A solid-liquid separation is performed in a secondary clarifier that follows the activated sludge process or by membrane filtration (membrane filtration is not covered in this chapter) that can be immersed in the activated sludge tank, and

3. One or more sludge and/or water recirculation devices are incorporated between relevant reactors and the secondary clarifier.

Activated sludge systems are frequently used in combination with other sanitation technologies. They are typically located after pretreatment and primary treatment of the wastewater and before advanced tertiary treatment (e.g. chemical, UV disinfection, activated carbon adsorption and/or sand filtration) (see Advanced Tertiary Processes Chapter) and/or anaerobic digestion (see Anaerobic Digestion Reactors Chapter) and/or sludge management (see Sludge Management Chapter) for further removal of pathogens, nutrients, organics, and suspended solids.

Activated sludge systems are classified by the applied load which can be expressed as mass or volumetric loading; for example, $\mathrm{kg} \mathrm{BOD} / \mathrm{kg}$ organic matter/day or $\mathrm{kg} \mathrm{BOD} / \mathrm{m}^{3}$ reactor/day, from very high load to very low load (3.0-6.0 to less than 0.07-0.3), with better treatment performances at lower loading. BOD removal can be quite high in a well designed and operated system, ranging from $75 \%$ to more than 95\%. However, greater removal efficiencies need greater oxygen inputs and transfer systems. For more information about design requirements of activated sludge process, please refer to von Sperling, (2007), WEF (2010), Grady et al. (2011), and Metcalf and Eddy et al. (2016). Historical information on pathogen fate in activated sludge systems is available in Feachem et al. $(1981,1983)$. 


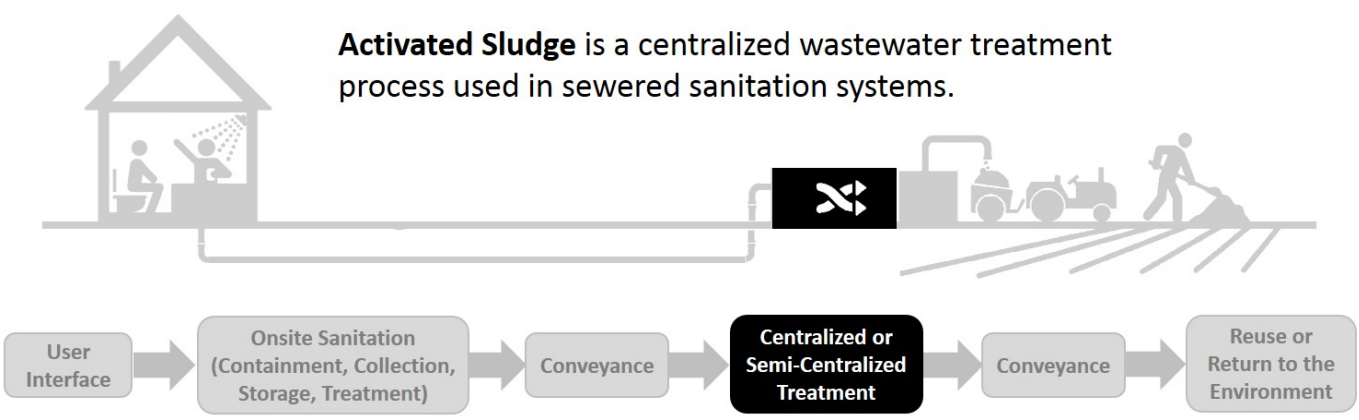

Figure 1. Location of activated sludge systems in the overall sanitation chain

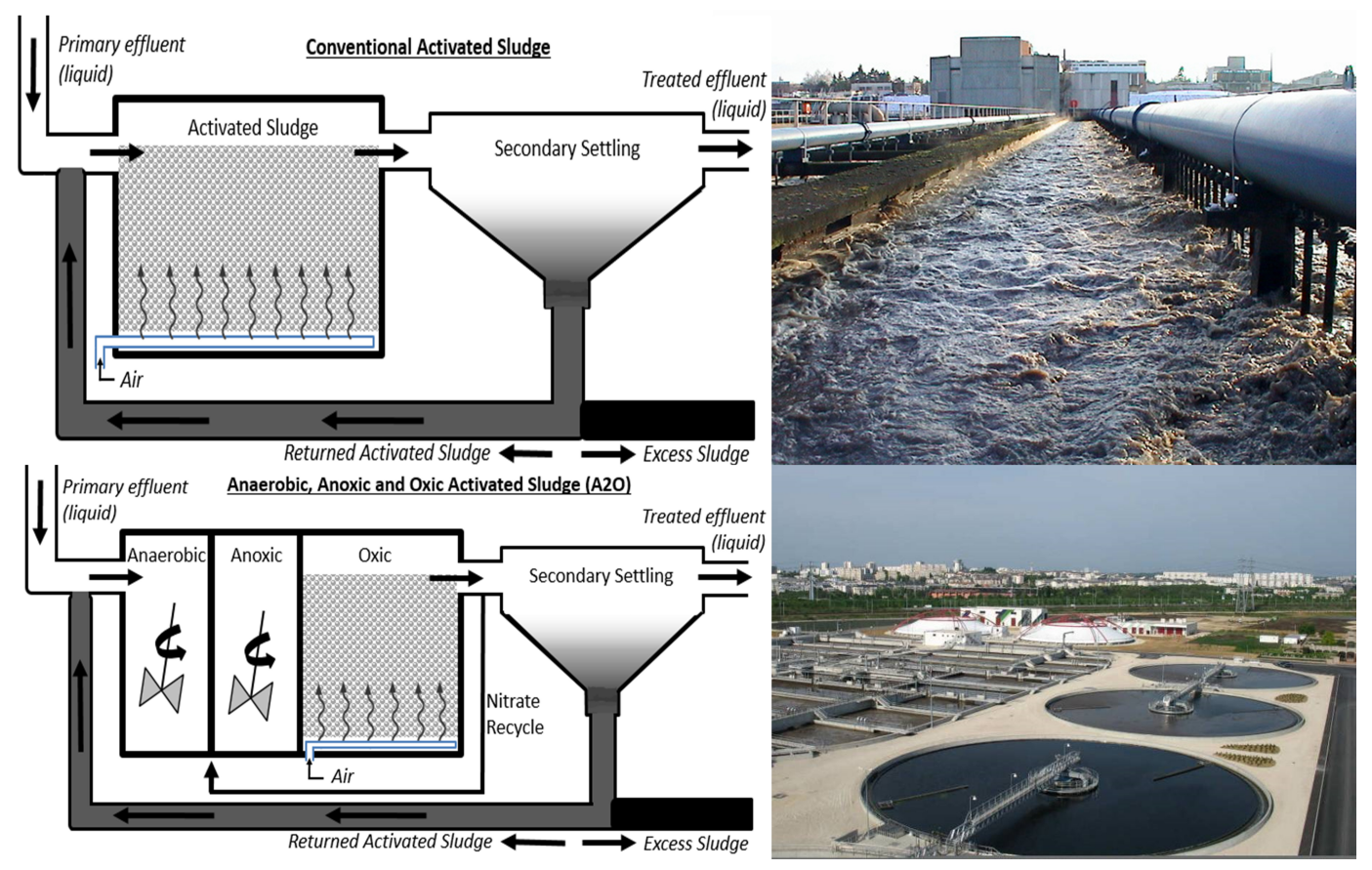

Figure 2. Schematic of a conventional activated sludge system (top left) with an example of this system in two large wastewater treatment plants in Paris, France; a high load activated sludge tank (top right) and secondary settlings tanks located after an anoxic and oxic activated sludge system (A2O) (bottom right). A schematic of an A2O system is included on the bottom left. Photos courtesy of SIAAPP (Syndicat Interdépartemental pour L'Assainissement de l'Agglomération Parisienne/The Interdepartmental Union for the Sanitation of the Parisian Conurbation).

\subsection{Inputs and Outputs for Activated Sludge Systems}

There are three major inputs to activated sludge systems in the form of liquids (wastewater and chemicals and stormwater in combined systems), solids (sludge), and air (mechanical mixing or aerators) while the three outputs are treated wastewater (liquid), sludge (solid), and bioaerosols and gases (air) (see Figure 3). As activated sludge systems are part of standard centralized or decentralized wastewater treatment plants, their inputs most often include domestic wastewater which may be mixed with stormwater and infiltration from the wastewater distribution system. Additionally, activated sludge systems are also used for the treatment of septage, industrial 
wastewaters, and landfill leachate.

Activated sludge treatment systems are usually placed after a preliminary treatment process (e.g., grit removal and screening) and primary settling of wastewater influent. However, extended aeration activated sludge plants (the most common type of package or prefabricated wastewater treatment plants often utilized for smaller communities, schools, or resorts) and oxidation ditch systems may not include a primary clarification/sedimentation step (Mihelcic and Zimmerman, 2014). Activated sludge systems also require aeration or mechanical mixing and, depending on the plant, various chemical inputs and exogenous carbon to facilitate nitrogen and phosphorus removal. Another major input into activated sludge systems is the settled sludge from the secondary clarifier after aeration or mixing, commonly referred to as Return Activated Sludge (RAS). RAS is regularly recirculated back into the aeration or mixing tank (see left side of Figure 2) to maintain the microbial communities at an operation-designated level. In fact, the secondary settled sludge becomes "activated" after the microorganisms are deprived of nutrients at the bottom of the secondary sedimentation tank and then returned to the aeration basin where there is a greater availability of nutrients.

The rest of the sludge, or Waste Activated Sludge (WAS), is a major output of the system and is either disposed of in a landfill or further treated (see Sludge Management Chapter). The second major output of activated sludge systems is the treated, liquid effluent that is either discharged directly to the environment, commonly into a nearby water body or undergoes further treatment (see Advanced Tertiary Processes Chapter). Gases such as nitrogen (N2), nitrous oxide (N2O), carbon dioxide (CO2), and even methane $(\mathrm{CH} 4)$ may be released from activated sludge systems from chemical reactions during treatment. A final output of activated sludge systems are bioaerosols particularly when the wastewater is agitated from the aeration and/or mixing stage that may contain pathogens that are dangerous to wastewater treatment operators or neighboring communities if ingested (Sanchez-Monedero et al., 2008; Wigginton et al., 2015).

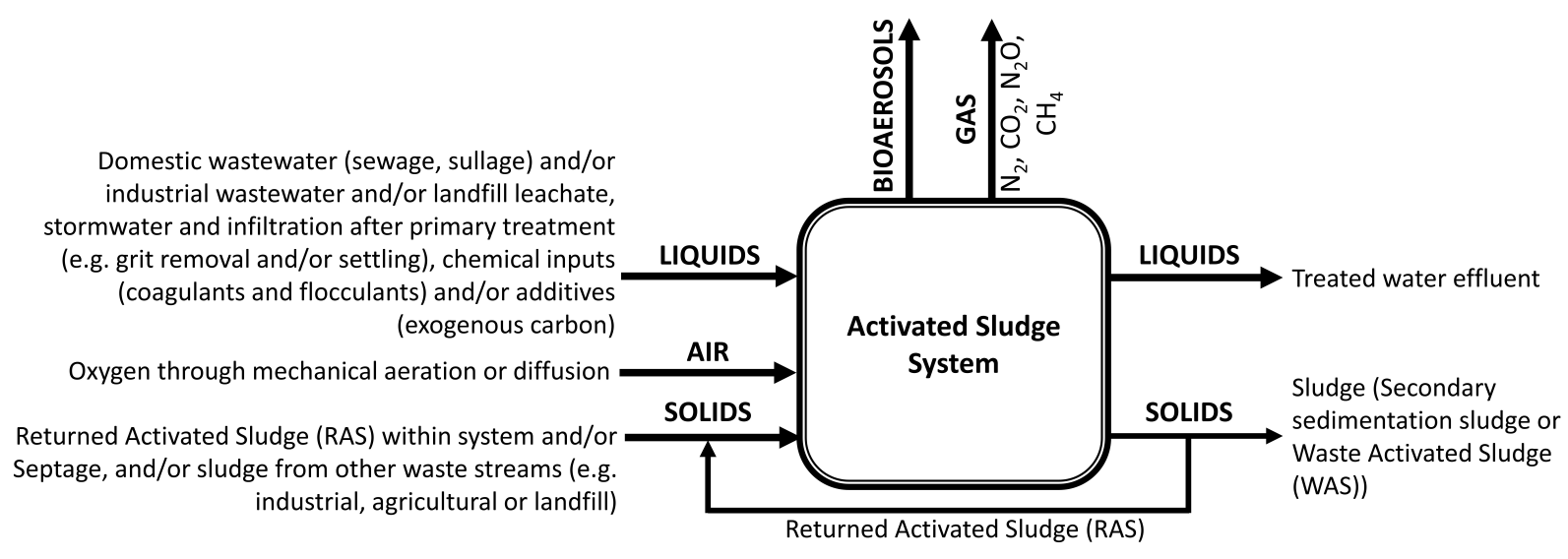

Figure 3. Typical inputs into and outputs from activated sludge systems

\subsection{Factors Affecting Pathogens in Activated Sludge Systems}

Feachem (1981) reported that activated sludge sanitation technologies can obtain between $0-2 \log _{10}$ removal of bacteria, $0-1 \log 10$ removal of viruses, $0-1 \log _{10}$ removal of protozoa, and $0-1 \log _{10}$ removal of helminths. However, the sludge produced often has high concentrations of pathogens that require further treatment (see Sludge Management Chapter) before safe land application (Bofill-Mas et al., 2006). Since Feachem (1981) was published, there have been many additional studies on pathogen removal conducted on full-scale treatment plants with activated sludge systems to add to primarily the mostly bench (laboratory) studies performed prior to 1980 . Review of this literature found an average $1.5 \log _{10}$ removal of bacteria, $1.8 \log _{10}$ removal of viruses and viral indicators, $1.3 \log _{10}$ removal of protozoa, and $0.65 \log _{10}$ removal of helminths (see Table 6 in the conclusion section). Figure 4 shows the major pathogen removal and inactivation mechanisms for activated sludge systems identified in the scientific literature including: (1) environmental factors, (2) operational factors, (3) microbiological factors, (4) physicalchemical factors, and (5) adsorption onto sludge. 


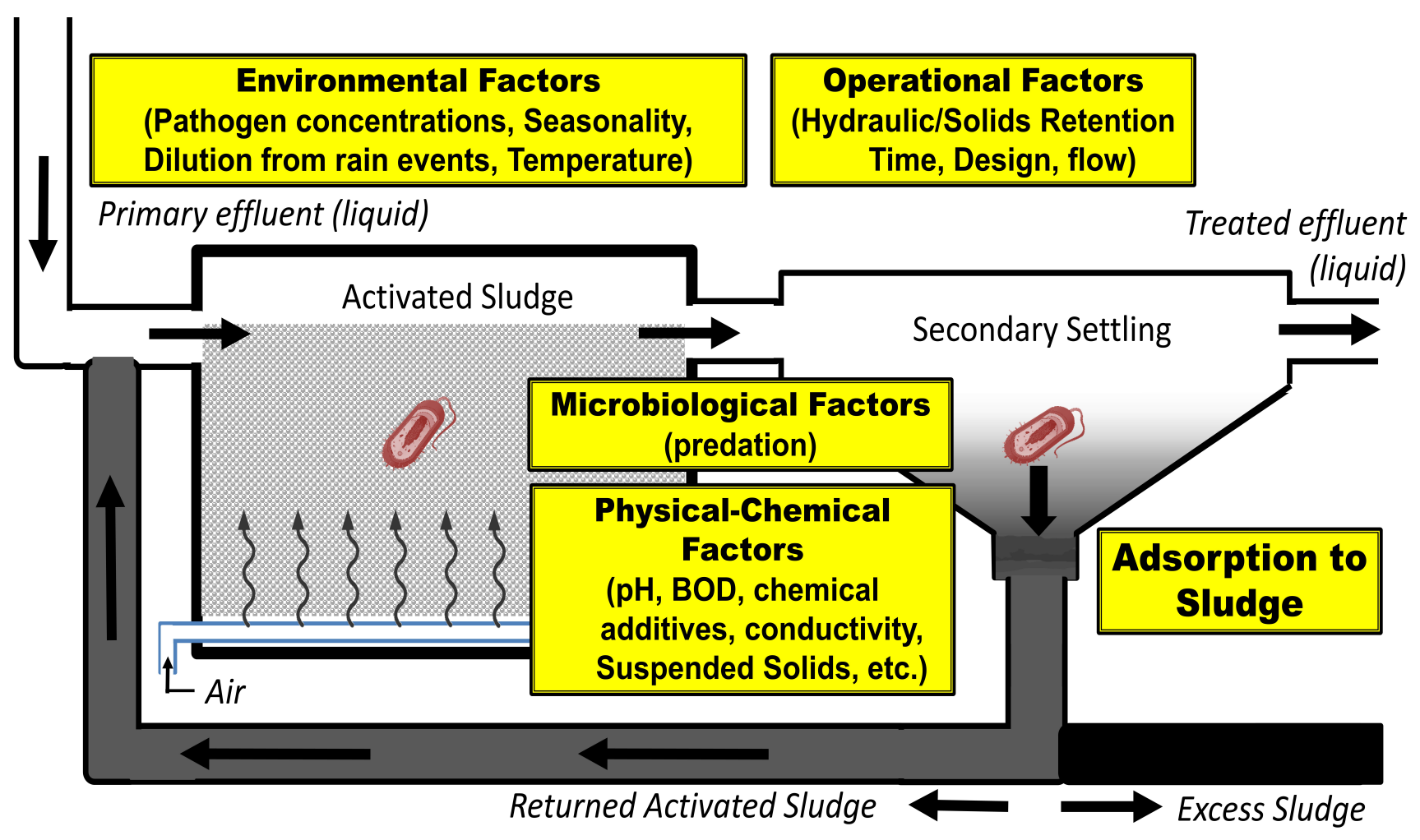

Figure 4. Major factors affecting pathogen removal in activated sludge systems

Overall, the two major pathogen removal factors continuously cited in the literature are adsorption onto sludge particles and predation from other microorganisms (microbiological factor) (Kim and Unno, 1996). However, design and operational factors (e.g., hydraulic retention time, solids retention time, flow rate, type of activated sludge process), physical-chemical factors ( $\mathrm{pH}, \mathrm{BOD}$, chemical additives, conductivity, suspended solids (SS)), environmental factors (seasonality, rain events, temperature, wind) are all of varying importance for pathogen inactivation and they are discussed in more detail below. Moreover, these different factors are interrelated so it is difficult to isolate individual factors especially in fullscale systems. For example, more denitrifying bacteria (a microbiological factor) are present in an $\mathrm{A} 2 \mathrm{O}$ process that may lead to higher predation of pathogens or environments less suitable for pathogens (e.g. more anoxic). These more advanced activated sludge systems have higher hydraulic retention times (HRTs) and/or Solids Retention Time (SRT) that also favor pathogen removal. Moreover, beyond HRT, the SRT and the presence of endogenous, anaerobic, anoxic zones in specific tanks, with specific development conditions (e.g. nutritional deficiency in carbon), for nitrogen and phosphorous advanced removal, before and inside the aerated zone, is an important factor for this predation (Gonçalvès et al. 2009).

\subsection{Adsorption}

Pathogens will adsorb to the sludge in the first part of the activated sludge system (Kim and Unno, 1996; Sano et al., 2004; Haramoto et al., 2007) and then are removed during secondary sedimentation or by membrane filtration. Adsorption is more of the major removal factor for viruses than bacteria (Wen et al., 2009). However, adsorption does not necessarily mean inactivation of the pathogens and thus may only transfer the pathogens from the liquid to the solid phase (Lasobras et al., 1999). The solid phase (i.e., the sludge) would then require further treatment or safe disposal. Furthermore, attachment of pathogens to sludge may be reversible during secondary settling or when the returned activated sludge is pumped back especially in an A2O process (Wen et al., 2009).

\subsection{Microbiological Factors}

Activated sludge systems have complex microbiological communities that compete for nutrients and also prey on each other that facilitate pathogen removal. Predation of pathogens by other organisms present in the activated sludge system is a major factor in pathogen removal (Kim 
and Unno, 1996). The food web of the activated sludge process is shown in Figure 5 and displays that a diverse group of microorganisms are present. Wen et al. (2009) stated that predation of bacteria by protozoa was significant but not the predation of viruses. Furthermore, a study that quantified virus-like particles found that activated sludge had higher numbers and diversity of viruses than wastewater influent, primary treatment effluent, and wastewater effluent, but less than anaerobically digesting sludge (Wu and Liu, 2009). These viral communities interact in complex and dynamic ways in the activated sludge environment and microbial community that may degrade and/or inactivate viruses. There are also many different types of microorganisms in wastewater (including algae, bacteria, protozoa, metazoa, etc.), but studies have been limited because only certain microorganisms can be measured ( $\mathrm{Wu}$ and Liu, 2009). Additionally, Katayama et al. (2008) and Gonçalvès et al. (2009) postulated that nitrifying bacteria and different bacteria accountable for nitrogen and phosphorus removal, especially autotrophic (e.g. nitrosomonas, nitrobacter etc.), in activated sludge systems may also assist in pathogen destruction and inactivation. When high mass charges are applied to the activated sludge, the formed flocs are small and the concentration of free bacteria is much smaller.

Indeed, the nutritional deficiency in carbon, necessary for the installation of the nitrifying autotrophic populations, accentuates the agglomeration of the free bacteria by flocculation, by activating the mechanism of transcription of the genes of secretions of exopolymers. Moreover, the selection of nitrifying autotrophic species is done to the detriment of the heterotrophic species including fecal bacteria. Finally, the age of activated sludge is important at very low load and is conducive to the development and maintenance of a microfauna bacteriophage (Gonçalvès et al. 2009). Certain types of protozoa like amoebas and metazoans (rotifers, gastrotriches, etc.) are predators of flocs and help to reduce the amount of bacteria present in flocculated form. Other ciliated protozoa belonging to the subclass of peritrichs, feed on free bacteria.

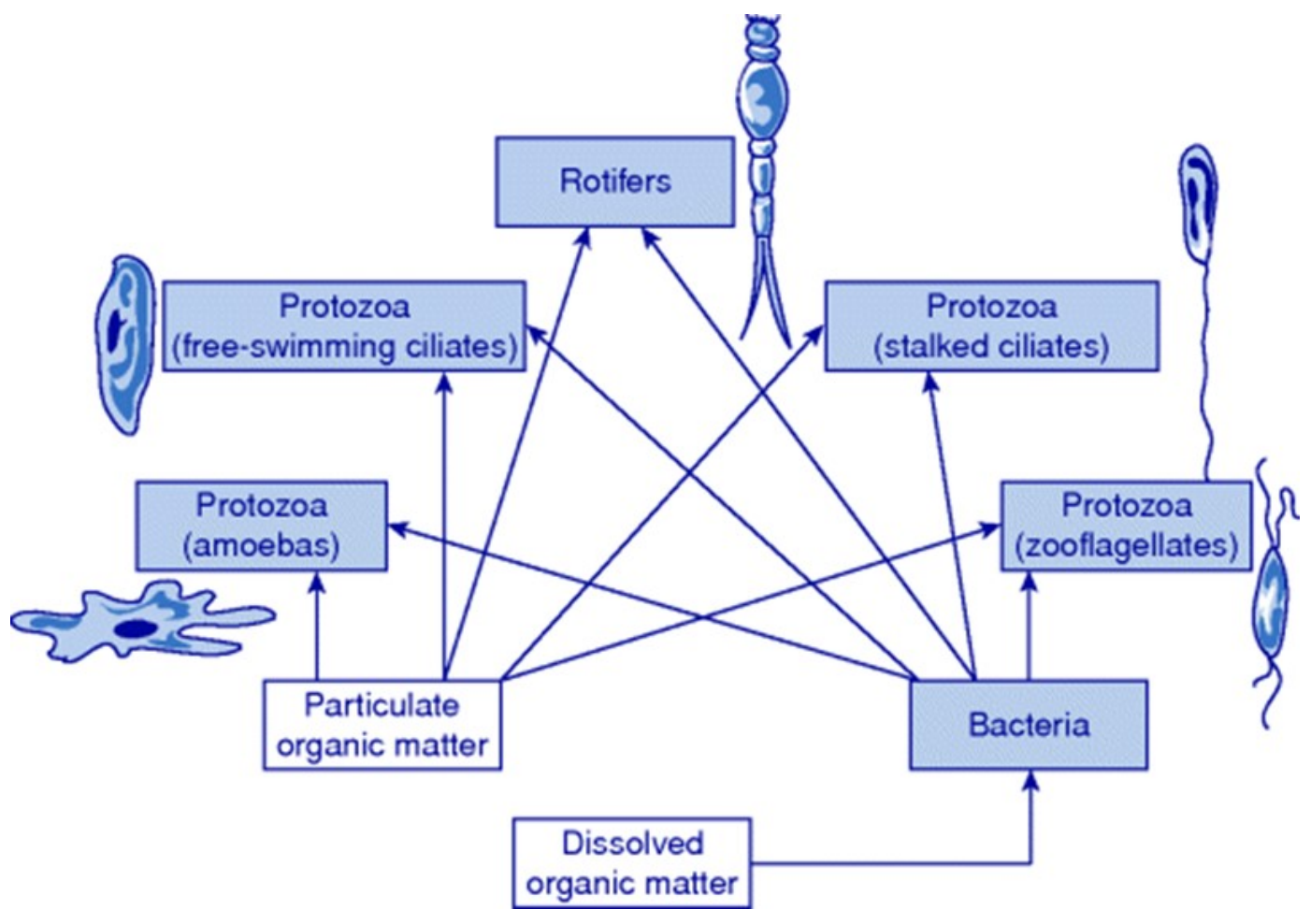

Figure 5. Food Web of the Activated-Sludge Process from Mihelcic (1999). Reprinted with permission of John Wiley \& Sons, Inc. Copyright $\odot 2014,2010$ John Wiley $\&$ Sons, Inc. All rights reserved. 


\subsection{Design and Operational Parameters}

Important design and operational parameters that may influence pathogen removal are hydraulic retention time (HRT), solids retention time (SRT), flow rate, reactor configuration (e.g., conventional activated sludge, A2O, sequencing batch reactor, oxidation ditch, package plants, etc.), and flow rate into the plant. First, regarding HRT, a greater HRT has been suggested to increase pathogen removal because it provides a longer time period for pathogen predation, natural decay, and inactivation (Katayama et al., 2008). Similarly a longer SRT is also favored to allow greater time for adsorption of pathogens onto activated sludge and inactivation (Sidhu et al., 2015). For example, Chen et al. (2012) documented a $3.75 \log _{10}$ removal of Salmonella with an SRT of 25 days and only a $1.9 \log _{10}$ removal with an SRT of 12 days.

Moreover, with improvements in activated sludge technology in general and particularly for nitrogen and phosphorus removal as discussed in the introduction, these systems may facilitate greater pathogen removal and bacteria morbidity and decay. This is because of the unfavorable conditions in which they are successively introduced. George et al. (2002) found greater removal in A2O plants than conventional activated sludge plants which may be due to the greater HRT and SRT of these systems and also the denitrifying bacteria that can consume the pathogens or compete with them for nutrients (see Microbiological Factors). In the Paris region, the studies by Moulin et al. (2010), Lucas et al. (2012), Gonçalvès et al. (2009), and Rocher et al. (2016) show that the conventional activated sludge systems simply removing the carbon at high loading (WWTP Seine aval historial processes, 6 million population equivalents: HRT of 0.25 day, SRT of 5 days) are much less effective for the removal of fecal contamination bacteria than the $\mathrm{A} 2 \mathrm{O}$ systems that treat nitrogen and phosphorus at an advanced level (WWTP Seine amont new processes, 2.4 million population equivalents: HRT of 0.8 day, SRT of 21 days). They show at least 1.5 to $2 \log _{10}$ unit of difference for E. coli average removal for example. However, Fu et al. (2009) found that an oxidation ditch process had greater removal of Cryptosporidium and Giardia than A20 and conventional activated sludge systems potentially because of the higher HRT.

The design flow rate or allowed inflow is also an important design factor for pathogen removal. This is usually more of a concern in regards to seasonality (see Environmental Factors section) with major rain events as this may dilute the pathogen concentrations, making removal more difficult. However, wastewater treatment plants can be designed to accommodate larger flows and/or incorporate combined sewer overflow storage (e.g., underground tunnels/tanks or retention basins) (EPA, 1999). Nodgren et al. (2009) found a negative correlation between incoming water flow and norovirus GGI and GGII reductions. Moreover, flow rate (Q) is closely related to HRT as HRT is equal to the volume of the tank divided by the flow rate (V/Q). A higher flow rate will reduce the HRT. You can increase HRT by increasing the size of the activated sludge system tanks but this also has higher capital and operating cost and you may be limited in the land available for the treatment plant.

Also the wastewater type accepted by the activated sludge system is important in determining the pathogen removal. More industrial or agricultural wastewaters or wastewaters from hospitals or communities with higher disease prevalence will impact the influent concentrations of pathogens and wastewater composition and potentially pathogen removal efficiencies. Prado et al. (2011) found that mean HAV virus concentrations in hospital waters were $2 \log _{10}$ higher than an urban sewage treatment plant in Brazil. Furthermore, whether the treatment plant accepts flow from combined or separated sewers will influence pathogen concentrations into the plant (Lucas et al., 2014). Combined sewer systems may lead to greater dilution and decreased HRT and, thus, lower pathogen removal efficiency and are more susceptible to storm events.

In regards to plant size, there hasn't been a significant relationship established with pathogen removal. Francy et al. (2012) compared a large and medium-sized wastewater treatment plant and did not find any statistically significant difference in pathogen $\log _{10}$ removals. However, there is more variability observed in the pathogen concentrations and removal efficiencies for smaller wastewater treatment plants (Sidhu et al., 2015).

\subsection{Physical-Chemical Parameters}

Physical-chemical parameters such as the $\mathrm{pH}$, conductivity, BOD, COD, suspended solids concentration, and chemical additives may also impact pathogen removal. Sidhu et al. (2015) reported varying results between studies in a literature review on whether these factors were significantly associated with pathogen removal in activated sludge systems. Some studies were able to identify a slight correlation while others were mostly not able to identify a correlation because it is difficult to isolate these factors in full-scale plants (Sidhu et al., 2015). Nevertheless, Koivenun et al. (2003) stated that efficient removal of suspended solids in secondary settling is important for pathogen removal because many pathogens adsorb onto the solids. Consequently, more efficient overall performance of a treatment plant in removal of suspended solids, BOD, and COD will aid pathogen removal (Koivenun et al., 2003). For example, Rose et al. (1996) found a positive correlation between coliphage removal and removal of CBOD and total suspended solids. The authors did not find such a positive correlation between coliphage and ammonia removal.

Moreover, Nodgren et al. (2009) found a correlation between higher conductivity and norovirus removal. Regarding $\mathrm{pH}$, acidic conditions $(\mathrm{pH} \leq 4)$ are more favorable for the adsorption of viruses onto solids and higher $\mathrm{pH}(\mathrm{pH}>8)$ may favor desorption but also inactivation (Sidhu et al., 2015). This has to do with the isoletric points of viruses or the $\mathrm{pH}$ at which they have no net electric charge. Below this point (lower $\mathrm{pH}$ ), viruses are positively charged and more likely to be attracted to other 
particles (Sidhu et al., 2015). However, the isoletric points vary for different viruses which makes it difficult to choose an optimal pH to remove all viruses. Lastly, Zhang and Farahbakhsh (2007) found that addition of ferrous chloride for phosphorus removal can increase the removal of coliforms and coliphages.

\subsection{Environmental Factors}

Environmental factors such as temperature, rainfall, wind, and seasonal weather variations and pathogen concentrations are also important for pathogen removal in activated sludge systems. Recent studies (e.g. Gonçalves et al., 2009; Gonçalves et al., 2011; Lucas et al., 2014) have focused more on environmental factors such as seasonality (wet and dry seasons) on pathogen removal efficiency. Rainy seasons and storm events may dilute fecal indicators and decrease removal efficiencies (Lucas et al., 2014). Another important component of seasonality, is the influent concentration of certain pathogens that vary depending on the season. For example, norovirus is typically endemic during colder months and the concentration was associated with seasonality in the study by Katayama et al. (2008). However, Nodgren et al. (2009) detected norovirus throughout the year where there were higher concentrations of norovirus GGI in the summer months and norovirus GGII concentrations were higher in the winter months. In tourist locations, there may also be seasonal variations in concentrations and influent flows due to the influx of tourists. Overall, through their literature review and sampling of activated sludge plants in Australia, Sidhu et al. (2015) found that not all studies have been able to find a statistically significant difference in pathogen removal due to seasonality and call for further research in this area. However, it is important to note that it may be difficult to find statistically significant seasonal differences in pathogen removal efficiencies in geographic areas such as Australia that have lower seasonal temperature variations.

Water temperature may also play an important role in pathogen removal efficiencies and inactivation in wastewater treatment plants. Li et al. (2011) found a higher concentration of rotavirus in three activated sludge plants in China during the winter months reasoning that rotavirus is more stable in colder temperatures and there is greater rotavirus inactivation in the summer with higher temperatures and UV from sunlight. Higher temperatures also facilitate greater adsorption by bacteria by enhancing the surface viscosity and physiology of microorganisms (Wen et al., 2009). Out of 14 environmental parameters, Lee et al. (2015) found that temperature was the only statistically significant variable to explain bacterial community variability in the bioreactor. King et al. (2005) found greater cryptosporidium oocyst inactivation at higher temperatures.

Lastly, the environmental factors of wind speed, humidity, solar radiation, and temperature are key environmental parameters that influence bioaerosol concentrations and their extent (Pascual et al., 2003; Karra and Katsivela, 2007). Higher wind speeds may cause greater distribution of bioaerosols emitted from activated sludge systems (Sanchez-Monedero et al., 2008) and potentially neighboring communities but reduce local concentrations (Pascual et al., 2003). Additionally, higher temperatures and solar radiation may more readily reduce bioaerosols (Karra and Katsivela, 2007). Bioaerosol concentrations are usually higher during night than day time with a lack of solar radiation and lower temperatures to reduce bioaerosols (Karra and Katsivela, 2007). Furthermore, bioaerosols may have higher concentrations in colder (winter and fall) months than warmer (spring and summer) months because of temperature differences (Malakootian et al., 2013). However, Fracchia et al. 2006 found no seasonal trends in bioaerosol concentrations in their study in Italy. In fact, Oppliger et al. (2005) found higher concentrations in the summer than winter in Switzerland and said that seasonal variations in bioaerosol concentrations will differ depending on the geographic location and their specific environmental parameters.

\subsection{Design, Operation and Maintenance Guidelines for Pathogen Removal}

As described previously, there are many different factors that influence pathogen removal in activated sludge systems. Although activated sludge systems are primarily designed for removal of organics, suspended solids, and nutrients (nitrogen and phosphorus), there are some operation and design parameters that can increase pathogen removal efficiencies. These are: greater solids and hydraulic retention times, lower influent flow rate and more storage during rain events, integrated nitrogen and phosphorous removal, and rate of aeration. Table 2 provides further information on the relationship between these parameters and the removal of different pathogen types.

Table 2. Summary of key factors and strategies to enhance pathogen removal efficiencies in activated sludge systems

\section{Factor \\ Pathogen removal is $\uparrow$ enhanced or $\downarrow$ reduced under the following conditions:}

Pathogen Groups Primarily Affected Bacteria Viruses Protozoa Helminths

\section{Water}

Temperature

Higher Temperature $=\uparrow$ Pathogen Removal

Hydraulic

Retention

Time

Longer Retention Time $=\uparrow$ Pathogen Removal

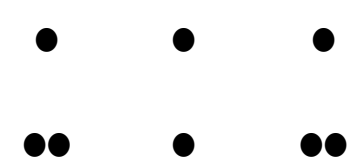




\section{Solids}

Retention

Time

Flow $^{\mathrm{a}}$

Bulking

Foam
Longer Retention Time $=\uparrow$ Pathogen Removal

Greater Flow $=\downarrow$ Pathogen Removal

Less flocculation $=\downarrow$ Pathogen Removal

More foam $=\downarrow$ Pathogen Removal

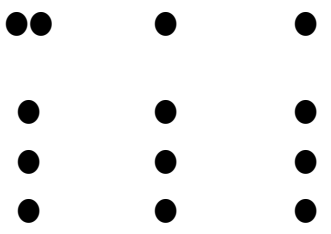

${ }^{\text {a }}$ A larger flow due to storm events in combined sewer systems may dilute pathogen concentrations and reduce hydraulic and solid retention times, thus inhibiting the normal functioning of activated sludge systems.

$\mathbf{0}=$ moderately affected; $\mathbf{0}=$ most affected

Proper operation and maintenance of activated sludge systems are crucial to efficient pathogen removal. Two of the major problems that can occur in activated sludge systems are bulking of sludge and production of foam (Crites and Tchobangolous, 1998). Bulking is caused when organisms do not flocculate together and thus do not efficiently settle during secondary settling. Gantzer et al. (1998) documented bulking in an activated sludge system over five days that decreased secondary settling yields and increased the concentrations of enteroviruses in the effluent by factors between 10 and 67. Biological surface foam can also form on the top of aeration and settling tanks which can be skimmed from the top and recycled in the system or reduced by addition of chemical agents such as polymers or chlorine (Tilley et al., 2014).

Additionally, activated sludge system design must take into account storm events especially when wastewater is coming from combined sewers and also prepare for electrical outages (e.g. backup generators to operate aerators). Wastewater treatment plants can include overflow storage of storm water, but these still may overflow and require the discharge of partially treated wastewater into water bodies with higher pathogen concentrations. Also, it may be advantageous to design activated sludge systems in colder climates with greater HRT and SRT or heating to allow for further time needed in removal because pathogen removal is more efficient with higher temperatures. Finally, the type of aeration devices and the aeration rate is important for the emission and movement of bioaerosols that can be harmful to wastewater treatment operators and local communities (SanchezMonedero et al, 2008). Air diffuser aerators are recommended as opposed to horizontal rotors and surface turbines because they have significantly lower bioaerosol emissions (see Table 3) (Sanchez-Monedero et al, 2008).

\subsection{Summary of Data on Pathogens in Activated Sludge Systems (Wastewater)}

Although individual studies may look at certain factors that influence the removal of pathogens in the wastewater of activated sludge systems, they do not always disclose key operational (e.g. HRT or SRT) or environmental parameters (temperature) so that removal efficiencies can better compared between studies. Also, many studies may base their removal efficiencies by comparing the wastewater after secondary settling or tertiary treatment to raw wastewater and not the wastewater after primary settling. Thus, studies that only included raw wastewater as influent were not included in this chapter the Figures and Tables below. Figure 6 includes a comparison of pathogen removal efficiencies with HRT and SRT from different studies where the influent sample was taken after primary settling and the effluent sample was taken after activated sludge and secondary settling. There doesn't appear to be a strong correlation between pathogen removal efficiency and HRT or SRT. However, this may be due to other factors of the individual treatment plants and studies.

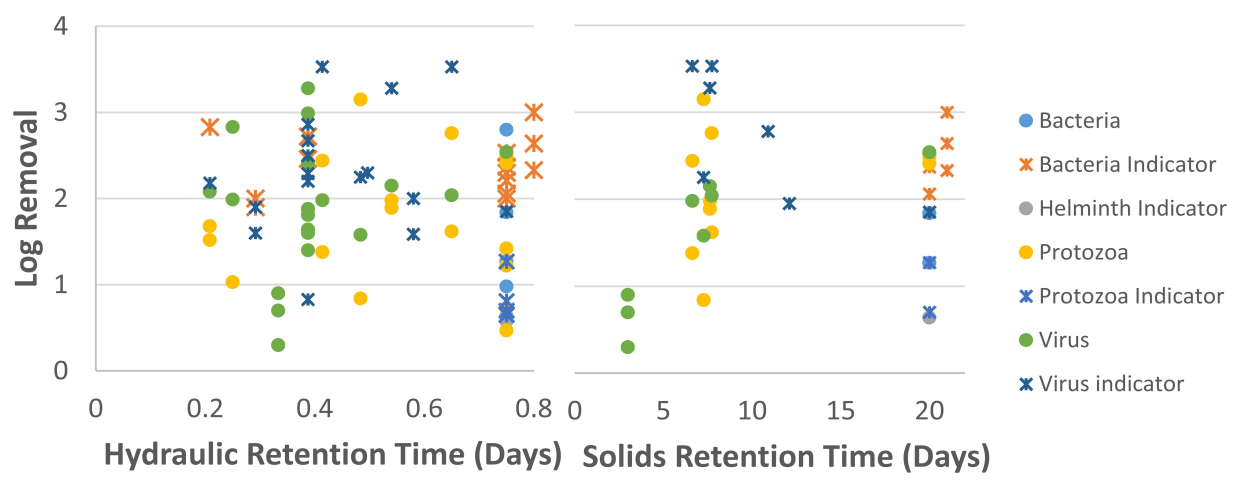

Figure 6. Relationship between hydraulic* and solids retention times and pathogen removal efficiencies in activated sludge systems. Sources : Schwartzbrod et al., 1987; Rose et al., 1996; George et al., 2002;

He and Jiang, 2005; Nordgren et al., 2009; Wen et al., 2009; Moulin et al., 2010; Li et al., 2011; Francy

et al., 2012; Lucas et al., 2012; De Luca et al., 2013; Ulbricht et al., 2014; Dias et al., 2015; Rocher et al., 2016. *Note that not all studies indicated whether the hydraulic retention time was for the entire plant, the activated sludge tank, and/or the secondary settling tank. 


\subsection{Summary of Data on Pathogens in Activated Sludge Systems (Sludge)}

There is much less data available for the pathogen removal efficiencies of the sludge in activated sludge systems than wastewater. Many studies mention that pathogens are transferred from the liquid phase to the solids (sludge) in activated sludge, however some removal does occur through pathogen degradation and predation. Wu and Liu (2009) found a $0.63 \log _{10}$ removal of virus-like particles while Lasobras et al. (1999) found a similar, 0.70 $\log _{10}$ removal of viral indicators and $1.48 \log _{10}$ removal of bacterial indicators (fecal coliforms and fecal streptococci). More information from other studies on the pathogen concentrations found in sludge is reported in Table 6 in the conclusion section.

\subsection{Summary of Data on Pathogens in Activated Sludge Systems (Bioaerosols)}

Bioaerosol concentrations from activated sludge systems are dependent on a number of operational and environmental parameters. When inhaled from the air or ingested after touching a surface contaminated with pathogenic bioaerosols, they can cause negative health consequences to sewage treatment workers such as stomach pain, fatigue, dizziness, eye irritation and headaches (Oppliger et al., 2005; Malakootian et al., 2013). Neighboring communities could also be at risk if concentrations are high enough and they are in close proximity to activated sludge treatment plants. Table 3 provides a summary of the microbial composition of bioaerosols in activated sludge systems depending on the type of aerator. Based on various studies, air supply oxidation, fine and micro bubble aerators generate the least amount of bioaerosols (Carducci et al. 2000; Karra and Katsivela, 2007; Sanchez-Monedero et al., 2008). More coarse bubble aeration, mechanical, horizontal rotors and paddle-mixers cause a lot of splashing and, thus, release of bioaerosols. For example, Fernando and Fedorak (2005) compared the bioaerosol emissions of a plant in 1976 that had coarse bubble aeration and was upgraded to fine bubble aeration and found that the bacterial counts of the upgrade were $1 \%$ of the original coarse bubble aeration values. Additionally, if activated sludge tanks are indoors without proper ventilation this can result in greater entrapped bioaerosols (Guo et al., 2014). An oxidation ditch system was enclosed in China because of the colder climate and installation of proper ventilation (e.g. a ventilator with a $50 \mathrm{~m}^{3} / \mathrm{min}$ flow rate for air exchange) reduced bioaerosols by over $50 \%$ (Guo et al., 2014).

Table 3. Bacterial composition $\left(\mathrm{CFU} / \mathrm{m}^{3}\right)$ of bioaerosols in activated sludge systems based on aerator type

\begin{tabular}{|c|c|c|c|c|c|c|c|c|c|c|}
\hline \multirow[b]{2}{*}{$\begin{array}{l}\text { Pathogen } \\
\text { Type }\end{array}$} & \multicolumn{10}{|c|}{ Aerator Type in Activated Sludge System } \\
\hline & $\begin{array}{l}\text { Paddle-Mixer } \\
\text { (Enclosed) }^{\mathrm{a}}\end{array}$ & $\begin{array}{c}\text { Rotated } \\
\text { Brush } \\
(\text { Enclosed) }\end{array}$ & Mechanical & $\begin{array}{c}\text { Horizontal } \\
\text { Rotor }^{\mathrm{e}}\end{array}$ & $\begin{array}{l}\text { Coarse } \\
\text { Bubble }^{f}\end{array}$ & $\begin{array}{l}\text { Blow } \\
\text { Dryer }^{g}\end{array}$ & Surface & $\begin{array}{c}\text { Fine } \\
\text { Bubble }\end{array}$ & $\begin{array}{l}\text { Micro } \\
\text { Bubble }\end{array}$ & $\begin{array}{l}\text { Air-supply } \\
\text { Oxidation }\end{array}$ \\
\hline $\begin{array}{l}\text { Bacterial } \\
\text { Count }\end{array}$ & 1,700 & $\begin{array}{c}3,021 \\
1,208(\mathrm{v})\end{array}$ & $1,623^{\mathrm{c}}$ & 3,036 & 1,400 & & $526^{\mathrm{e}, \mathrm{h}}$ & $140^{\mathrm{e}, \mathrm{i}}$ & 270 & 19 \\
\hline $\begin{array}{l}\text { Gram } \\
\text { negative } \\
\text { bacteria }\end{array}$ & - & - & $30.5^{\mathrm{d}}$ & - & & - & - & - & - & - \\
\hline $\begin{array}{l}\text { Heterotrophic } \\
\text { bacteria }\end{array}$ & - & - & - & - & - & 513 & - & - & - & - \\
\hline $\begin{array}{l}\text { Total } \\
\text { Coliforms }\end{array}$ & - & - & $39^{\mathrm{d}}$ & - & - & 203 & $211^{\mathrm{h}}$ & $1^{\mathrm{i}}$ & - & 2 \\
\hline $\begin{array}{l}\text { Fecal } \\
\text { Coliforms }\end{array}$ & - & - & - & - & - & 44 & $94^{\mathrm{h}}$ & $\mathrm{BDL}^{\mathrm{i}}$ & - & - \\
\hline E. coli & - & - & $14^{\mathrm{d}}$ & - & - & - & - & - & - & - \\
\hline Anaerobes & - & - & $39^{\mathrm{d}}$ & - & - & - & - & - & - & - \\
\hline Enterococci & - & - & - & - & - & - & - & $\mathrm{BDL}^{\mathrm{i}}$ & - & - \\
\hline $\begin{array}{l}\text { Fecal } \\
\text { Streptococci }\end{array}$ & - & - & - & - & - & - & $113^{\mathrm{h}}$ & - & - & - \\
\hline$P$. aeruginosa & - & - & - & - & - & 1 & - & - & - & - \\
\hline
\end{tabular}

A blank cell (-) indicates that the data were not reported; BDL: Below detection limit; (v): with ventilation

Sources: ${ }^{a}$ Bauer et al., 2002; ${ }^{b}$ Guo et al., 2014; ${ }^{\circ}$ Brandi et al., 2000; ${ }^{d}$ Fracchia et al., 2006; ' Sánchez-Monedero et al., 2008; ${ }^{\mathrm{f}}$ Fernando and Fedorak, 2005; ${ }^{9}$ Pascual et al. 2003; ${ }^{\mathrm{h}}$ Malakootian et al., 2013; ${ }^{\mathrm{i}}$ Karra and Katsivela, 2007; ${ }^{\mathrm{j}} \mathrm{Li}$ et al., 2016; ${ }^{\mathrm{k}}$ Carducci et al., 2000 
Activated sludge systems include more than the activated sludge tank but also the secondary settling tank, waste activated and return activated sludge, and may include sampling sinks for the Mixed Liquor Suspended Solids (MLSS) for the activated sludge to ensure it is operating properly. Table 4 displays the range of bacteria in bioaerosols in the different components of the activated sludge system from various studies. Mostly, the aeration tank had the highest and broadest range of bioaerosols but the sampling sinks and waste activated sludge can also have larger concentrations especially if they are enclosed. Fernando and Fedorak (2005) found that a wastewater treatment plant upgrade that replaced the original, automated sampling sinks where all taps would run simultaneously with a $0.3 \mathrm{~m}$ drop with sampling sinks where taps run at separate times and go either through plastic tubing or drop a short distance $(10 \mathrm{~cm})$ to a trough significantly reduced the number of bioaerosol bacterial counts.

Table 4. Bacterial composition $\left(\mathrm{CFU} / \mathrm{m}^{3}\right)$ of bioaerosols in different components of activated sludge systems

\begin{tabular}{|c|c|c|c|c|c|}
\hline \multirow[b]{2}{*}{ Pathogen Type } & \multicolumn{5}{|c|}{ Activated Sludge System Component } \\
\hline & Aeration Tank & $\begin{array}{c}\text { Secondary Settling } \\
\text { Tank }\end{array}$ & $\begin{array}{c}\text { MLSS } \\
\text { Sampling Sink } \\
\text { (0.3 m Drop) }^{\mathrm{g}}\end{array}$ & $\begin{array}{l}\text { MLSS Sampling Sink } \\
\text { (10 cm Drop into } \\
\text { Trough/Tubing) })^{g}\end{array}$ & $\begin{array}{c}\text { Waste Activated } \\
\text { Sludge Thickening } \\
\text { Tank } \\
\text { (Enclosed) }^{\mathrm{g}} \\
\end{array}$ \\
\hline$\overline{\text { Bacterial Count }}$ & $19^{\mathrm{a}}$ to $3,036^{\mathrm{b}}$ & $49^{\mathrm{d}}$ & 55 to 620 & 3 to 38 & 68 to 830 \\
\hline Total Coliforms & $1^{\mathrm{c}}$ to $211^{\mathrm{d}}$ & $1^{\mathrm{c}}$ to $15^{\mathrm{d}}$ & - & - & - \\
\hline Fecal Coliforms & $\mathrm{BDL}^{\mathrm{e}}$ to $94^{\mathrm{f}}$ & $\mathrm{BDL}^{\mathrm{c}}$ to $6^{\mathrm{d}}$ & - & - & - \\
\hline Enterococci & $\mathrm{BDL}^{\mathrm{e}}$ & $\mathrm{BDL}^{\mathrm{c}}$ & - & - & - \\
\hline $\begin{array}{l}\text { Fecal } \\
\text { Streptococci }\end{array}$ & $113^{\mathrm{d}}$ & $13^{\mathrm{d}}$ & - & - & - \\
\hline
\end{tabular}

A blank cell (-) indicates that the data were not reported; BDL: Below detection limit

Sources: ${ }^{\mathrm{a}}$ Carducci et al., 2000; ${ }^{\mathrm{b}}$ Sánchez-Monedero et al., 2008; ${ }^{\mathrm{C}}$ Karra and Katsivela, 2007; ${ }^{\mathrm{d}}$ Malakootian et al., 2013; ${ }^{\mathrm{e}}$ Karra and Katsivela, 2007; ${ }^{\mathrm{f}}$ Malakootian et al., 2013; ${ }^{9}$ Fernando and Fedorak, 2005

Bioaerosols may be transported through dispersion through the air and by wind away from their source. Table 5 displays ranges and numbers of bacteria in bioaerosols from activated sludge systems upwind and downwind from treatment plants. In general, bioaerosol numbers decreased at further distances and were low at upwind locations. Average air samples away from wastewater treatment plants will still have bioaerosols present naturally and from other human and animal sources. Also downwind samples may contain bioaerosols from other components of the wastewater treatment plant including primary treatment and settling which have been found to have larger bioaerosol emissions than activated sludge (Karra and Katsivela, 2007). Again, as seen in Table 2, fine bubble diffused air systems had lower concentrations than mechanical aeration systems (Brandi et al., 2000) and lower bioaerosol concentrations were found during the day than at night. Moreover, other studies measured bioaerosol concentrations at different heights above aeration tanks and found decreasing concentrations with greater heights (Sawyer et al., 1996; Fernando and Fedorak, 2005). However, many studies do not report the sampling height or distance. 
Table 5. Microbial numbers and composition in bioaerosols $\left(\mathrm{CFU} / \mathrm{m}^{3}\right)$ at different distances up and downwind from activated sludge treatment plants

\begin{tabular}{|c|c|c|c|c|c|c|c|}
\hline \multirow[b]{2}{*}{ Pathogen Type } & \multicolumn{7}{|c|}{ Distances from Activated Sludge Treatment Plants } \\
\hline & $\begin{array}{c}2 \mathrm{~m} \\
\text { Upwind }^{\mathrm{a}}\end{array}$ & 2m Downwind ${ }^{a}$ & $\begin{array}{c}\text { 10m } \\
\text { Downwind }^{\mathrm{a}}\end{array}$ & Upwind $^{\text {b }}$ & $\begin{array}{c}<150 \mathrm{~m} \\
\text { Downwind }^{\mathrm{b}}\end{array}$ & $\begin{array}{l}150 \text { to } 250 \mathrm{~m} \\
\text { Downwind }^{\mathrm{b}}\end{array}$ & $\begin{array}{c}>250 \mathrm{~m} \\
\text { Downwind }^{\mathrm{b}}\end{array}$ \\
\hline $\begin{array}{l}\text { Bacterial Count } \\
\left(\mathrm{CFU} / \mathrm{m}^{3}\right)\end{array}$ & 5.5 & $\begin{array}{l}11.1 \text { to } 290^{\mathrm{c}} \\
483 \text { to } 1817^{\mathrm{d}}\end{array}$ & $\begin{array}{l}11.1 \text { to } 171^{\mathrm{c}} \\
245 \text { to } 1383^{\mathrm{d}}\end{array}$ & $\begin{array}{c}52 \text { to } \\
179\end{array}$ & 272 to 373 & 115 to 175 & 191 to 194 \\
\hline $\begin{array}{l}\text { Total Coliforms } \\
\left(\mathrm{CFU} / \mathrm{m}^{3}\right)\end{array}$ & BDL & $\begin{array}{c}\mathrm{BDL}^{\mathrm{c}} \\
75.2 \text { to } 967^{\mathrm{d}}\end{array}$ & $\begin{array}{l}11.1 \text { to } 290^{\mathrm{c}} \\
37.2 \text { to } 366^{\mathrm{d}}\end{array}$ & $\begin{array}{c}0.09 \text { to } \\
0.22\end{array}$ & 5.17 to 6.81 & 0.57 to 0.86 & 0.34 to 0.40 \\
\hline $\begin{array}{l}\text { Fecal Coliforms } \\
\left(\mathrm{CFU} / \mathrm{m}^{3}\right)\end{array}$ & BDL & $\begin{array}{c}\mathrm{BDL}^{\mathrm{c}} \\
\text { BDL to } 54.1^{\mathrm{d}}\end{array}$ & $\begin{array}{c}\mathrm{BDL}^{\mathrm{c}} \\
\text { BDL to } 16.6^{\mathrm{d}}\end{array}$ & 0.01 & 1.67 to 2.09 & 0.18 to 0.64 & 0.15 to 0.29 \\
\hline E. coli $\left(\mathrm{CFU} / \mathrm{m}^{3}\right)$ & $\mathrm{BDL}$ & $\mathrm{BDL}$ & $\mathrm{BDL}$ & - & - & - & - \\
\hline $\begin{array}{l}\text { Fecal } \\
\text { Streptococci } \\
\left(\mathrm{CFU} / \mathrm{m}^{3}\right)\end{array}$ & - & - & - & $\begin{array}{c}0.04 \text { to } \\
0.83\end{array}$ & 0.29 to 2.07 & 0.15 to 1.21 & 0.48 to 0.86 \\
\hline $\begin{array}{l}\text { Staphylococci } \\
\left(\mathrm{CFU} / \mathrm{m}^{3}\right)\end{array}$ & BDL & $\begin{array}{l}12.4 \text { to } 24.9^{\mathrm{c}} \\
25.9 \text { to } 100^{\mathrm{d}}\end{array}$ & $\begin{array}{l}6.9 \text { to } 11.1^{\mathrm{c}} \\
25 \text { to } 183^{\mathrm{d}}\end{array}$ & - & - & - & - \\
\hline $\begin{array}{l}\text { Coliphages } \\
\left(\mathrm{PFU} / \mathrm{m}^{3}\right)\end{array}$ & - & - & - & 0.012 & 0.073 & 0.049 & 0.076 \\
\hline
\end{tabular}

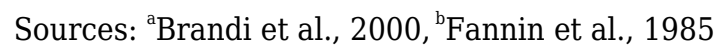

A blank cell (-) indicates that the data were not reported; BDL: Below detection limit; ${ }^{c}$ Fine bubble diffused air system; ${ }^{\mathrm{d}}$ Mechanical aeration

\subsection{Conclusions}

Table 6 provides a summary of typical pathogen removal efficiencies in activated sludge systems for wastewater (influent sample taken after primary settling and effluent taken after secondary settling). Review of this literature found an average $1.5 \log _{10}$ removal of bacteria, $1.8 \log _{10}$ removal of viruses and viral indicators, $1.3 \log _{10}$ removal of protozoa, and $0.65 \log _{10}$ removal of helminths. Table 7 includes the concentration of pathogens in the secondary sludge. There is a lot of variation of removal efficiencies between different activated sludge reactor configurations and also between the same reactor configuration depending on the plant's influent characteristics, environmental and operational parameters.
Therefore, pathogen removal efficiency should be validated at each individual activated sludge plant. Although higher hydraulic and solids retention times are favored this does not exclusively lead to greater pathogen removal efficiency. Based on the pathogen concentrations and removal efficiencies of activated sludge systems both in the wastewater and sludge, further tertiary treatment may be required (see Advanced Tertiary Treatment Chapter) before releasing into water bodies, recycling treated wastewater, or applying on land (see Sludge Management Chapter) especially for viruses. Nevertheless, activated sludge systems are an efficient technology to remove the majority of pathogens especially activated sludge systems that also emphasize biological nitrogen and even phosphorus removal. 
Table 6. Summary of results from literature review for average and range $\log _{10}$ pathogen removal from wastewater in different types of activated sludge systems

\begin{tabular}{|c|c|c|c|c|c|}
\hline \multirow{2}{*}{$\begin{array}{l}\text { Activated Sludge } \\
\text { System Type }\end{array}$} & \multicolumn{5}{|c|}{$\begin{array}{c}\text { Typical Pathogen and Fecal Indicator } \log _{10} \text { Removal Values a } \\
\text { (Typical Ranges Shown in Parentheses) }\end{array}$} \\
\hline & $\begin{array}{l}\text { Bacterial } \\
\text { Pathogens }\end{array}$ & $\begin{array}{l}\text { Viruses and } \\
\text { Indicators }\end{array}$ & $\begin{array}{l}\text { Protozoa and } \\
\text { Indicators }\end{array}$ & $\begin{array}{l}\text { Helminth Eggs } \\
\text { and Indicators }\end{array}$ & $\begin{array}{c}\text { Fecal Coliforms } \\
\text { (Including } E . \\
\text { coli) }\end{array}$ \\
\hline Conventional & $\begin{array}{c}1.12 \\
(0.44 \text { to } 2.30)\end{array}$ & $\begin{array}{c}2.02 \\
(0.63 \text { to } 3.53)\end{array}$ & $\begin{array}{c}1.40 \\
(0.11 \text { to } 3.15)\end{array}$ & $>0.60$ & $\begin{array}{c}1.80 \\
(1.00 \text { to } 2.89)\end{array}$ \\
\hline $\begin{array}{l}\text { Anaerobic, Anoxic, and } \\
\text { Oxic Activated Sludge } \\
\text { System (A2O) }\end{array}$ & $\begin{array}{c}1.96 \\
(0.98 \text { to } 2.80)\end{array}$ & $\begin{array}{c}1.61 \\
(0.30 \text { to } 2.83)\end{array}$ & $\begin{array}{c}1.31 \\
(0.70 \text { to } 2.49)\end{array}$ & $\begin{array}{c}0.61 \\
(0.58 \text { to } 0.64)\end{array}$ & $\begin{array}{c}2.39 \\
(2.06 \text { to } 3.00)\end{array}$ \\
\hline $\begin{array}{l}\text { Sequencing Batch } \\
\text { Reactors }\end{array}$ & - & 1.15 & - & - & 1.0 \\
\hline
\end{tabular}

A blank cell (-) indicates that the data were not reported; Conventional Activated Sludge treatment sources: Casson et al., 1990; Stadterman et al., 1995; Rose et al., 1996; Robertson et al., 2000; Saleem et al., 2000; George et al., 2002; Caccio et al., 2003; Zhang and Farahbakhsh, 2007; Cheng et al., 2009; Wu and Liu, 2009; Flapper et al., 2010; Fu et al., 2010; Gonçalves et al., 2009; Gonçalves et al., 2011; Li et al., 2011; Muela et al., 2011; Francy et al., 2012; Hata et al., 2013; Keegan et al., 2013; De Luca et al., 2013; Dias et al., 2015; Qiu et al., 2015; Rocher et al. 2016

A20 treatment sources: Yasunori et al., 2002; Gonçalves et al., 2009; Nordgren et al., 2009; Wen et al., 2009; Fu et al., 2010; Moulin et al., 2010; Li et al., 2011; Ulbricht et al., 2014, Lucas et al., 2012; Lucas et al., 2014

Sequencing Batch Reactor source: Ng et al., 1993

Table 7. Typical concentrations of pathogens and fecal indicators in sludge samples after secondary sedimentation in activated sludge systems

\begin{tabular}{lcccc}
\hline Bacterial Pathogens & Virus Indicators & Protists & Helminth Eggs & $\begin{array}{c}\text { Fecal Coliforms } \\
\text { (including E. coli) }\end{array}$ \\
1.5 to $1.9 \mathrm{E}+07 \mathrm{MPN} / \mathrm{g}^{\mathrm{a}}$ & $\begin{array}{c}2.8 \mathrm{E}+05 \text { to } 1.1 \mathrm{E}+09 \\
\text { microorganisms } / \mathrm{g}\end{array}$ & $\begin{array}{c}4 \text { to } 19 \\
\text { (oo)cysts } / \mathrm{g}\end{array}$ & BDL to $0.125 \mathrm{eggs} / \mathrm{g}$ & $2 \mathrm{to} 2.8 \mathrm{E}+07 \mathrm{MPN} / \mathrm{g}$
\end{tabular}

Sources: Schwartzbrod et al., 1989; Lasobras et al., 1999; Dehab and Surampalli, 2002; Garrec et al., 2003; Cheng et al., 2009

${ }^{a}$ Per gram of dry matter; BDL: Below Detection Limit 


\section{References}

Bauer, H., Fuerhacker, M., Zibuschka, F., Schmid, H. and Puxbaum, H. (2002). Bacteria and fungi in aerosols generated by two different types of wastewater treatment plants. Water Research. 36, pp. 3965-3970. doi: 10.1016/S0043-1354(02)00121-5.

Bofill-Mas, S., Albinana-Gimenez, N., Clemente-Casares, P., Hundesa, A., Rodriguez-Manzano, J., Allard, A. et al. (2006). Quantification and stability of human adenoviruses and polyomavirus JCPyV in wastewater matrices. Applied and Environmental Microbiology. 72, pp. 7894-7896. doi: 10.1128/AEM.00965-06.

Brandi, G., Sisti, M. and Amagliani, G. (2000). Evaluation of the environmental impact of microbial aerosols generated by wastewater treatment plants utilizing different aeration systems. Journal of Applied Microbiology. 88, pp. 845-852. doi: 10.1046/j.1365-2672.2000.01024.x.

Cacciò, S.M., De Giacomo, M., Aulicino, F.A. and Pozio, E. (2003). Giardia Cysts in Wastewater Treatment Plants in Italy. Applied and Environmental Microbiology. 69, pp. 3393-3398. doi: 10.1128/AEM.69.6.3393-3398.2003.

Carducci, A., Tozzi, E., Rubulotta, E., Casini, B., Cantiani, L., Rovini, E. et al. (2000). Assessing airborne biological hazard from urban wastewater treatment. Water Research. 34, pp. 1173-1178. doi: 10.1016/S0043-1354(99)00264-X.

Carducci, A. and Verani, M. (2013). Effects of Bacterial, Chemical, Physical and Meterological Variables on Virus Removal by a Wastewater Treatment Plant. Food and Environmental Virology. 5, pp. 69-76.

Casson, L.W., Sorber, C.A., Sykora, J.L., Gavaghan, P.D., Shapiro, M.A. and Jakubowski, W. (1990). Giardia in WastewaterEffect of Treatment Giardia in wastewater?. Research Journal of the Water Pollution Control Federation. 62, pp. 670-675.

Cheng, H.W.A., Lucy, F.E., Graczyk, T.K., Broaders, M.A., Tamang, L. and Connolly, M. (2009). Fate of Cryptosporidium parvum and Cryptosporidium hominis oocysts and Giardia duodenalis cysts during secondary wastewater treatments. Parasitology Research. 105, pp. 689-696. doi: 10.1007/s00436-009-1440-y.

Chen, Y., Fu, B., Wang, Y., Jiang, Q. and Liu, H. (2012). Reactor performance and bacterial pathogen removal in response to sludge retention time in a mesophilic anaerobic digester treating sewage sludge. Bioresource Technology. 106, pp. 20-26. doi: 10.1016/j.biortech.2011.11.093.

Crites, R. and Tchobangolous, G. (1998). Small and Decentralized Wastewater Management Systems. McGraw-Hill. New York.

Dahab, M.F. and Surampalli, R.Y. (2002). Effects of aerobic and anaerobic digestion systems on pathogen and pathogen indicator reduction in municipal sludge. Water Science and Technology. 46, pp. 181-187.

De Luca, G., Sacchetti, R., Leoni, E. and Zanetti, F. (2013). Removal of indicator bacteriophages from municipal wastewater by a full-scale membrane bioreactor and a conventional activated sludge process: Implications to water reuse. Bioresource Technology. 129, pp. 526-531. doi: 10.1016/j.biortech.2012.11.113.

Dias, E., Ebdon, J. and Taylor, H. (2015). The application of removal coefficients for viruses in different wastewater treatment processes calculated using stochastic modelling. Water Science and Technology. 71, pp. 1382-1388. doi: 10.2166/wst.2015.086.

EPA (1999). Combined Sewer Overflow Technology Fact Sheet. U.S. Environmental Protection Agency. pp. 1-11. doi: EPA 832-F-99-041.

Fannin, K.F., Vana, S.C. and Jakubowski, W. (1985). Effect of an Activated Sludge Wastewater Treatment Plant on Ambient Air Densities of Aerosols Containing Bacteria and Viruses. Applied and Environmental Microbiology. 49, pp. 1191-1196.

Feachem, R.G., Bradley, D.J., Garelick, H. and Mara, D.D. (1981). Appropriate Technology for Water Supply and Sanitation: Health Aspects of Excreta and Sullage Management- A State-of-the-Art Review. World Bank. 
Fernando, N.L. and Fedorak, P.M. (2005). Changes at an activated sludge sewage treatment plant alter the numbers of airborne aerobic microorganisms. Water Research. 39, pp. 4597-4608. doi: 10.1016/j.watres.2005.08.010.

Flapper, T., Campbell, B. and O'Connor, N. (2010). Final Report: Pathogen reduction in Australian activated sludge plants. SWF Project. pp. 1-96. doi: 10.1115/1.802915.ch1.

Fracchia, L., Pietronave, S., Rinaldi, M. and Martinotti, M.Giovanna (2006). Site-related airborne biological hazard and seasonal variations in two wastewater treatment plants. Water Research. 40, pp. 1985-1994. doi: 10.1016/j.watres.2006.03.016.

Francy, D.S., Stelzer, E.A., Bushon, R.N., Brady, A.M.G., Williston, A.G., Riddell, K.R. et al. (2012). Comparative effectiveness of membrane bioreactors, conventional secondary treatment, and chlorine and UV disinfection to remove microorganisms from municipal wastewaters. Water Research. 46, pp. 4164-4178. doi: 10.1016/j.watres.2012.04.044.

Fu, C.Y., Xie, X., Huang, J.J., Zhang, T., Wu, Q.Y., Chen, J.N. et al. (2010). Monitoring and evaluation of removal of pathogens at municipal wastewater treatment plants. Water Science and Technology. 61, pp. 1589-1599. doi: 10.2166/wst.2010.757.

Gantzer, C., Maul, A., Audic, J.M. and Schwartzbrod, L. (1998). Detection of infectious enteroviruses, enterovirus genomes, somatic coliphages, and Bacteroides fragilis phages in treated wastewater. Applied and Environmental Microbiology. 61, pp. 4307-4312.

Garrec, N., Picard-Bonnaud, F. and Pourcher, A.M. (2003). Occurrence of Listeria sp. and L. monocytogenes in sewage sludge used for land application: Effect of dewatering, liming and storage in tank on survival of Listeria species. FEMS Immunology and Medical Microbiology. 35, pp. 275-283. doi: 10.1016/S0928-8244(02)00443-1.

George, I., Crop, P. and Servais, P. (2002). Fecal coliform removal in wastewater treatment plants studied by plate counts and enzymatic methods. Water Research. 36, pp. 2607-2617. doi: 10.1016/S0043-1354(01)00475-4.

Goncalves, A., Rocher, V., Masnada, S., Lucas, F., Moulin, L. and Thomasset, T. (2011). Elimination de la pollution microbienne sur les stations d'epuration du SIAAP: synopsis des differents procedes de traitment. SIAAP. pp. 1-21.

Goncalves, A., Rocher, V. and Pichon, S. (2009). Qualite bacteriologique des eaux de la region parisienne. TSM. 3, pp. 38-49.

Grady, C.P.Leslie, Daigger, G.T., Love, N.G. and Filipe, C.D.M. (2011). Biological Wastewater Treatment. 3rd ed. IWA Publishing. London, UK. pp. 1022.

Guo, X., Wu, P., Ding, W., Zhang, W. and Li, L. (2014). Reduction and characterization of bioaerosols in a wastewater treatment station via ventilation. Journal of Environmental Sciences (China). 26, pp. 1575-1583. doi: 10.1016/j.jes.2014.06.001.

Haramoto, E., Katayama, H., Oguma, K. and Ohgaki, S. (2007). Quantitative analysis of human enteric adenoviruses in aquatic environments. Journal of Applied Microbiology. 103, pp. 2153-2159. doi: 10.1111/j.1365-2672.2007.03453.x.

Hata, A., Kitajima, M. and Katayama, H. (2013). Occurrence and reduction of human viruses, F-specific RNA coliphage genogroups and microbial indicators at a full-scale wastewater treatment plant in Japan. Journal of Applied Microbiology. 114, pp. 545-554. doi: 10.1111/jam.12051.

He, J.W. and Jiang, S. (2005). Quantification of enterococci and human adenoviruses in environmental samples by real-time PCR. Applied and Environmental Microbiology. 71, pp. 2250-2255. doi: 10.1128/AEM.71.5.2250-2255.2005.

Karra, S. and Katsivela, E. (2007). Microorganisms in bioaerosol emissions from wastewater treatment plants during summer at a Mediterranean site. Water Research. 41, pp. 1355-1365. doi: 10.1016/j.watres.2006.12.014.

Katayama, H., Haramoto, E., Oguma, K., Yamashita, H., Tajima, A., Nakajima, H. et al. (2008). One-year monthly quantitative survey of noroviruses, enteroviruses, and adenoviruses in wastewater collected from six plants in Japan. Water Research. 42, pp. 1441-1448. doi: 10.1016/j.watres.2007.10.029. 
Keegan, A.R., Robinson, B., Monis, P., Biebrick, M. and Liston, C. (2013). Validation of activated sludge plant preformance for virus and protozoan reduction. Journal of Water Reuse and Desalination. 3, pp. 140-147. doi: 10.2166/wrd.2013.032.

Kim, T.D. and Unno, H. (1996). The Roles of Microbes in the Removal and Inactivation of Viruses in a Biological Wastewater Treatment System. Water Science and Technology. 33, pp. 243-250.

King, J.K., Keegan, A.R., Monis, P.T. and Saint, C.P. (2005). Environmental Temperature Controls Cryptosporidium Oocyst Metabolic Rate and Associated Retention of Infectivity. Applied and Environmental Microbiology. 71, pp. 3848-3857. doi: 10.1128/AEM.71.7.3848-3857.2005.

Koivunen, J., Siitonen, A. and Heinonen-Tanski, H. (2003). Elimination of enteric bacteria in biological-chemical wastewater treatment and tertiary filtration units. Water Research. 37, pp. 690-698. doi: 10.1016/S0043-1354(02)00305-6.

Lasobras, J., Dellunde, J., Jofre, J. and Lucena, F. (1999). Occurrence and levels of phages proposed as surrogate indicators of enteric viruses in different types of sludges. Journal of Applied Microbiology. 86, pp. 723-729.

Lee, S.Hoon, Kang, H.Jin and Park, H.Deung (2015). Influence of influent wastewater communities on temporal variation of activated sludge communities. Water Research. 73, Elsevier Ltd. pp. 132-144. doi: 10.1016/j.watres.2015.01.014.

Li, D., Gu, A.Z., Zeng, S.Y., Yang, W., He, M. and Shi, H.C. (2011). Monitoring and evaluation of infectious rotaviruses in various wastewater effluents and receiving waters revealed correlation and seasonal pattern of occurrences. Journal of Applied Microbiology. 110, pp. 1129-1137. doi: 10.1111/j.1365-2672.2011.04954.x.

Li, J., Zhou, L., Zhang, X., Xu, C., Dong, L. and Yao, M. (2016). Bioaerosol emissions and detection of airborne antibiotic resistance genes from a wastewater treatment plant. Atmospheric Environment. 124, pp. 404-412. doi: 10.1016/j.atmosenv.2015.06.030.

Lucas, F., Goncalves, A., Servais, P., Rocher, V., Masnada, S., Therial, C. et al. (2012). Variabilité de la qualité microbiologique des eaux usées brutes dans une grande agglomération. TSM Numero 4. 107, pp. 44-55.

Lucas, F.S., Therial, C., Goncalves, A., Servais, P., Rocher, V. and Mouchel, J.Marie (2014). Variation of raw wastewater microbiological quality in dry and wet weather conditions. Environmental Science and Pollution Research. 21, pp. 5318-5328. doi: 10.1007/s11356-013-2361-y.

Malakootian, M., Radhakrishna, N., Pourshaaban, M.P. and Hossaini, H. (2013). Bacterial-aerosol emission from wastewater treatment plant. Desalination and Water Treatment. 51, pp. 4478-4488. doi: 10.1080/19443994.2013.769668.

Tchobanoglous, G., H. Stensel, D., Tsuchihashi, R. and Burton, F. (2014). Wastewater Engineering: Treatment and Reuse. 5th ed. McGraw-Hill Education. New York.

Mihelcic, J.R. (1999). Fundamentals of Environmental Engineering. John Wiley and Sons. New York.

Mihelcic, J.R. and Zimmerman, J.B. (2014). Environmental Engineering: Fundamentals, Sustainability, Design. 2nd ed. John Wiley and Sons. New York.

Moulin, L., Richard, F., Stefania, S., Goulet, M., Gosselin, S., Goncalves, A. et al. (2010). Contribution of treated wastewater to the microbiological quality of Seine River in Paris. 44, pp. 5222-5231. doi: 10.1016/j.watres.2010.06.037.

Muela, A., Orruño, M., Alonso, M.L., Pazos, M., Arana, I., Alonso, R.M. et al. (2011). Microbiological parameters as an additional tool to improve wastewater treatment plant monitoring. Ecological Indicators. 11, pp. 431-437. doi: 10.1016/j.ecolind.2010.06.014.

Muga, H.E. and Mihelcic, J.R. (2008). Sustainability of wastewater treatment technologies. Journal of Environmental Management. 88, pp. 437-447. doi: 10.1016/j.jenvman.2007.03.008.

Ng, W.J., Sim, T.S., Ong, S.L., Ng, K.Y., Ramasamy, M. and Tan, K.N. (1993). Fate of coliforms and coliphages in the sequencing batch reactor (SBR). Bioresource Technology. 46, pp. 197-205. doi: 10.1016/0960-8524(93)90120-Z. 
Nordgren, J., Matussek, A., Mattsson, A., Svensson, L. and Lindgren, P.E. (2009). Prevalence of norovirus and factors influencing virus concentrations during one year in a full-scale wastewater treatment plant. Water Research. 43, pp. 1117-1125. doi: 10.1016/j.watres.2008.11.053.

Nordgren, J., Matussek, A., Mattsson, A., Svensson, L. and Lindgren, P.E. (2009). Prevalence of norovirus and factors influencing virus concentrations during one year in a full-scale wastewater treatment plant. Water Research. 43, pp. 1117-1125. doi: 10.1016/j.watres.2008.11.053.

Oppliger, A., Hilfiker, S. and Duc, T.V. (2005). Influence of seasons and sampling strategy on assessment of bioaerosols in sewage treatment plants in Switzerland. Annals of Occupational Hygiene. 49, pp. 393-400. doi: 10.1093/annhyg/meh108.

Pascual, L., Perez-Luz, S., Yanez, A.M., Santamaria, A., Gibert, K., Salgot, M. et al. (2003). Bioaerosol Emissions From Wastewater Treatment Plants. Aerobiologia. 41, pp. 261-270.

Prado, T., Silva, D.M., Guilayn, W.C., Rose, T.L., Gaspar, A.M.C. and Miagostovich, M.P. (2011). Quantification and molecular characterization of enteric viruses detected in effluents from two hospital wastewater treatment plants. Water Research. 45, pp. 1287-1297. doi: 10.1016/j.watres.2010.10.012.

Qiu, Y., Lee, B.E., Neumann, N., Ashbolt, N., Craik, S., Maal-Bared, R. et al. (2015). Assessment of human virus removal during municipal wastewater treatment in Edmonton, Canada. Journal of Applied Microbiology. 119, pp. 1729-1739. doi: 10.1111/jam.12971.

Robertson, L.J., Paton, C.A., Campbell, A.T., Smith, P.G., Jackson, M.H., Gilmour, R.A. et al. (2000). Giardia cysts and Cryptosporidium oocysts at sewage treatment works in Scotland, UK. Water Research. 34, pp. 2310-2322. doi: 10.1016/S0043-1354(99)00408-X.

Rocher, V., Goncalves, A. and Mailler, R. (2016). Elimination des bactéries indicatrices fécales en station d ' épuration E cacité des di érents procédés I. Introduction. pp. 43-63.

Rose, J.B., Dickson, L.J., Farrah, S.R. and Carnahan, R.P. (1996). Removal of pathogenic and indicator microorganisms by a full-scale water reclamation facility. Water Research. 30, pp. 2785-2797. doi: 10.1016/S0043-1354(96)00188-1.

Sánchez-Monedero, M.A., Aguilar, M.I., Fenoll, R. and Roig, A. (2008). Effect of the aeration system on the levels of airborne microorganisms generated at wastewater treatment plants. Water Research. 42, pp. 3739-3744. doi: 10.1016/j.watres.2008.06.028.

Saleem, M., Bukhari, A.A. and Al-Malack, M.H. (2000). Removal Efficiencies of Indicator Micro-organisms in the Al-Khobar Wastewater Treatment Plant. Environmental Engineering Science. 17, pp. 227-232. doi: 10.1089/10928750050137570.

Sano, D., Matsuo, T. and Omura, T. (2004). Virus-Binding Proteins Recovered from Bacterial Culture Derived from Activated Sludge by Affinity Chromatography Assay Using a Viral Capsid Peptide. Applied and Environmental Microbiology. 70, pp. 3434-3442. doi: 10.1128/AEM.70.6.3434-3442.2004.

Sawyer, B., Rao, K.C., O'Brien, P., Elenbogen, G., Zenz, D.R. and Lue-Hing, C. (1996). Changes in Bacterial Aerosols with Height above Aeration Tanks. Journal of Environmental Engineering. pp. 368-373.

Schwartzbrod, J., Stien, J.L., Bouhoum, K. and Baleux, B. (1989). Impact of Wastewater Treatment on Helminth Eggs. Water Science and Technology. 21, pp. 295-297.

Schwartzbrod, J., Bouhoum, K. and Baleux, B. (1987). Effects of lagoon treatment on helminth eggs. Water Science and Technology. 19, pp. 33-40.

Sidhu, J.P.S., Ahmed, W., Hodgers, L., Smith, K., Palmer, A., Wylie, J. et al. (2015). Development of Validation Protocol for Activated Sludge Process in Water Recycling. Australian Water Recycling Centre of Excellence. Brisbane, Australia.

Stadterman, K.L., Sninsky, A.M., Sykora, J.L. and Jakubowski, W. (1995). Removal and inactivation of cryptosporidium oocysts by activated sludge treatment and anaerobic digestion. Water Science and Technology. 31, pp. 97-104. 
Tilley, E., Ulrich, L., Luethi, C., Reymond, P. and Zurbruegg, C. (2014). Compendium of Sanitation Systems and Technologies. 2nd ed. Swiss Federal Institute of Aquatic Science and Technology (Eawag). Duebendorf, Switzerland.

Ulbricht, K., Selinka, H.C., Wolter, S., Rosenwinkel, K.H. and Nogueira, R. (2014). A mass balance approach to the fate of viruses in a municipal wastewater treatment plant during summer and winter seasons. Water Science and Technology. 69, pp. 364-370. doi: 10.2166/wst.2013.722.

von Sperling, M. (2007). Activated Sludge and Aerobic Bioflim Reactors. Biological Wastewater Treatment Series. 5 ed. International Water Association (IWA) Publishing. London.

Water Environment Federation (2010). Design of Municipal Treatment Plants: WEF Manual of Practice, No. 8. ASCE Manuals and Reports on Engineering Practice No. 76. McGraw-Hill Education. New York.

Wen, Q., Tutuka, C., Keegan, A. and Jin, B. (2009). Fate of pathogenic microorganisms and indicators in secondary activated sludge wastewater treatment plants. Journal of Environmental Management. 90, pp. 1442-1447. doi: 10.1016/j.jenvman.2008.09.002.

Wigginton, K.R., Ye, Y. and Ellenberg, R.M. (2015). Emerging investigators series: the source and fate of pandemic viruses in the urban water cycle. Environmental Science: Water Research and Technology. 1, pp. 725-924. doi: 10.1039/C5EW00125K.

Wu, Q. and Liu, W.T. (2009). Determination of virus abundance, diversity and distribution in a municipal wastewater treatment plant. Water Research. 43, Elsevier Ltd. pp. 1101-1109. doi: 10.1016/j.watres.2008.11.039.

Yasunori, T., Katsunori, M., Masatoshi, Y., Masatomo, M., Katsutoshi, H. and Hajime, U. (2002). Fate of coliphage in a wastewater treatment process. Journal of Bioscience and Bioengineering. 94, pp. 172-174. doi: 10.1016/S1389-1723(02)80139-6.

Zhang, K. and Farahbakhsh, K. (2007). Removal of native coliphages and coliform bacteria from municipal wastewater by various wastewater treatment processes: Implications to water reuse. Water Research. 41, pp. 2816-2824. doi: 10.1016/j.watres.2007.03.010. 